\title{
ANALISIS FUNGSI AKTIVASI JARINGAN SYARAF TIRUAN UNTUK MENDETEKSI KARAKTERISTIK BENTUK GELOMBANG SPEKTRA BABI DAN SAPI
}

\author{
Shofwan Ali Fauji \\ Mahasiswa PPs Institut Teknologi Sepuluh Nopember Surabaya \\ e-mail: shofwan.ali.fauji@gmail.com
}

\begin{abstract}
ABSTRAK
Jaringan Syaraf Tiruan (JST) sedikit demi sedikit mulai mampu menggantikan tugas seorang pakar, bahkan dengan JST mampu dibuat alat untuk menggantikan seorang dokter. Salah satu jenis JST adalah jaringan Backpropagation, jaringan ini dapat digunakan untuk melakukan pelatihan agar program mampu mengenali apakah itu gelombang spektra babi atau sapi. Untuk menentukan keluaran dalam pelatihan Backpropagation dibutuhkan fungsi aktivasi yang cocok. Karena itu pada penelitian ini akan dibandingkan beberapa fungsi aktivasi yang dapat digunakan dalam pelatihan. Fungsi aktivasi-fungsi aktivasi itu diuji coba dengan tes rasio untuk mengetahui interval kekonvergenannya. Setelah diuji coba dengan tes rasio didapatkan bahwa fungsi aktivasi tanh $z$ adalah fungsi aktivasi yang paling bagus untuk digunakan pelatihan jaringan Backpropagation, karena memiliki rentang bobot yang dapat memenuhi metode-metode yang digunakan dalam penentuan bobot. Setelah diuji coba dengan data, fungsi aktivasi $\tanh z$ mampu mengenali data uji coba dengan tepat semua. Diharapkan pada penelitian selanjutnya untuk meneliti interval bobot yang membuat pelatihan mencapai konvergensi dengan cepat dan errornya sedikit.
\end{abstract}

Kata kunci:Fungsi Sigmoid Biner, Gelombang Spektra Sapi Dan Bab, Jaringan Backpropagation

\section{ABSTRACT}

Artificial Neural Network (ANN) is beginning little by little to replace the task of an expert, even with the ANN can be a tool to replace a doctor. One of kind of ANN is Backpropagation networks, this network can be used to training programs in order to be able to recognize whether it is pig or cow wave spectra. To determine the output in Backpropagation training required suitable activation functions. Therefore, in this research will be compared to some of the activation function that can be used in training. Activation functions will be tested with the ratio test to determine the interval convergence. After tested with the ratio test it was found that the activation function tanh $\mathrm{z}$ was the best activation function to use the Backpropagation network training, because it has a weight range that can meet the methods used in the determination of weights. When tested with the data, the activation function $\tanh \mathrm{z}$ is able to recognize correctly all trial datas. Expected in future research to examine the weight that makes the interval training to achieve fast convergence and the error bit.

Keywords:Backpropagation Networks, Binary Sigmoid Function, Wave Spectra in The Case of Cows and Pigs

\section{PENDAHULUAN}

Babi adalah hewan yang haram dimakan. Berbagai penelitian ilmiah dan medis membuktikan bahwa dibandingkan hewanhewan yang lain, babi tergolong paling berpotensi membawa virus dan bakteri yang membahayakan tubuh manusia (Ahmad, 2008). Semua jenis makanan yang diharamkan Allah SWT selalu bersifat kotor dan semua yang kotor mencakup semua obyek yang dapat merusak kehidupan, kesehatan, harta dan moral manusia. Haramnya babi dapat dilihat pada surat al-An'am ayat 145. Sebagai mahluk hidup babi juga memiliki protein, dari protein itulah dapat diketahui gelombang spektra babi. Dan untuk membandingkannya maka digunakan gelombang spektra makanan yang halal dan sering digunakan sebagai bahan makanan masyarakat luas, yaitu sapi. Berikut gambar gelombang spektra sapi dan babi yang digambar dengan alat fourier transform (FTIR).

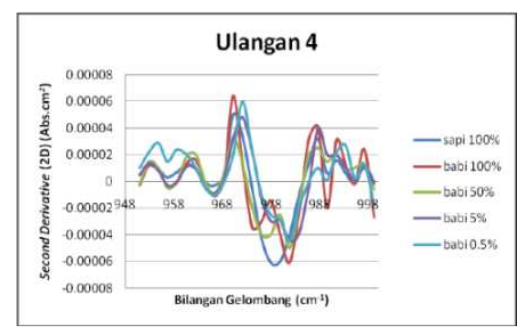

Gambar 1. Turunan kedua spektra infra merah sapi dan babi dengan alat FTIR 
Selanjutnya dalam penelitian ini akan dikaji kaitan jaringan syaraf tiruan (JST) dalam pendeteksian makanan yang mengandung babi atau tidak.

JST dipilih karena JST sistem pemroses informasi yang memiliki karakteristik mirip dengan jaringan syaraf biologi (Siang, 2009). Seperti halnya otak manusia, JST juga terdiri beberapa neuron dan ada hubungan antara neuron-neuron tersebut. Neuron-neuron tersebut akan mentransformasikan informasi yang diterima melalui sambungan keluarnya menuju ke neuron-neuron yang lain. Pada JST informasi tersebut disimpan pada suatu nilai tertentu yang disebut bobot. JST dibentuk sebagai generalisasi model matematika dari jaringan syaraf biologi, dengan asumsi bahwa:

- Pemrosesan informasi terjadi pada banyak elemen sederhana (neuron).

- Sinyal dikirimkan diantara neuron-neuron melalui penghubung-penghubung.

- Penghubung antar neuron memiliki bobot yang akan memperkuat dan memperlemah sinyal.

- Untuk menentukan keluaran, setiap neuron menggunakan fungsi aktivasi (biasanya non linier) yang dikenakan pada jumlahan masukan yang diterima. Besarnya keluaran ini selanjutnya dibandingkan dengan suatu batas ambang.

\section{KAJIAN TEORI}

\section{Matriks}

Matriks adalah jajaran elemen berbentuk empat persegi panjang (Purwanto, et al., 2005). Bentuk (ukuran) matriks ditentukan oleh banyaknya baris dan kolom. Untuk selanjutnya matriks matriks yang mempunyai $m$ baris dan $n$ kolom dituliskan sebagai matriks berukuran $m \times n$ (misalnya matriks A berukuran $3 x 4$ ), dan ukuran ini biasa disebut dengan ordo matriks. Berikut ini adalah beberapa contoh matriks.

$$
\boldsymbol{A}=\left[\begin{array}{ll}
3 & 2 \\
1 & 4
\end{array}\right] \boldsymbol{B}=\left[\begin{array}{l}
6 \\
7
\end{array}\right]
$$

Matriks-matriks di atas ber-ordo, $\boldsymbol{A}=2 \times 2, \boldsymbol{B}=2 \times 1$. Matriks yang hanya mempunyai satu kolom disebut matriks kolom seperti matriks $\boldsymbol{B}$, atau sering juga disebut dengan vektor.

Seperti halnya bilangan riil, matriksmatriks juga bisa ditambahkan, dikurangkan dan dikalikan dengan cara yang berguna (Anton, 2000).

Definisi. Dua matriks didefinisikan sama jika keduanya mempunyai ukuran yang sama dan unsur-unsurnya berpadanan sama.

Dalam notasi matriks, $\boldsymbol{A}=\left[a_{i j}\right]$ dan $\boldsymbol{B}=\left[b_{i j}\right]$ mempunyai ukuran yang sama, maka
$\boldsymbol{A}=\boldsymbol{B}$ jika dan hanya jika $a_{i j}=b_{i j}$ untuk semua $i$ dan $j$. Contohnya adalah:

$$
\boldsymbol{A}=\left[\begin{array}{ll}
3 & 4 \\
6 & 5
\end{array}\right] \boldsymbol{B}=\left[\begin{array}{ll}
3 & 4 \\
6 & 5
\end{array}\right]
$$

Dari contoh itu terlihat bahwa matriks $\boldsymbol{A}$ dan $\boldsymbol{B}$ sama secara ukuran dan unsur-unsurnya.

Definisi. Jika $\boldsymbol{A}$ dan $\boldsymbol{B}$ adalah matriksmatriks berukuran sama, maka jumlah $\boldsymbol{A}+\boldsymbol{B}$ adalah matriks yang diperoleh dengan menambahkan unsur-unsur matriks $\boldsymbol{A}$ dengan unsur-unsur $\boldsymbol{B}$ yang berpadanan. $\boldsymbol{A}-\boldsymbol{B}$ adalah matriks yang diperoleh dengan mengurangkan unsur-unsur $\boldsymbol{A}$ dengan unsur-unsur $\boldsymbol{B}$ yang berpadanan. Matriks-matriks berukuran berbeda tidak bisa ditambahkan atau dikurangkan.

Definisi. Jika $\boldsymbol{A}$ adalah sebarang matriks dan $c$ adalah sebarang skalar, maka hasil kali $\boldsymbol{c A}$ adalah matriks yang diperoleh dengan mengalikan setiap unsur $\boldsymbol{A}$ dan $c$.

Definisi. Jika $\boldsymbol{A}$ adalah sebuah matriks $m \times r$ dan $\boldsymbol{B}$ adalah sebuah matriks $r \times n$, maka hasil kali $\boldsymbol{A} \boldsymbol{B}$ adalah matriks $m \times n$ yang unsurunsurnya didefinisikan sebagai berikut. Untuk mencari unsur dalam baris $i$ dan kolom $j$ dari $\boldsymbol{A B}$, pilih baris $i$ dari matriks $\boldsymbol{A}$ dan kolom $j$ dari matriks B. Kalikan unsur-unsur yang berpadanan dari baris dan kolom secara bersama-sama dan kemudian jumlahkan hasil kalinya.

Definisi. Perkalian matriks mensyaratkan bahwa jumlah kolom matriks $\boldsymbol{A}$ sama dengan jumlah baris matriks $\boldsymbol{B}$ untuk membentuk hasil kali AB. Jika syarat ini tidak terpenuhi, hasil kalinya tidak terdefinisi.

\section{Citra}

Citra adalah suatu representasi (gambaran), kemiripan, atau imitasi dari suatu objek (Sutoyo, et al., 2009). Citra sebagai keluaran suatu sistem perekaman data dapat bersifat optik berupa foto, bersifat analog berupa sinyal-sinyal video seperti gambar pada monitor televisi atau bersifat digital yang dapat langsung disimpan pada suatu media penyimpanan. Citra dapat dibagi menjadi dua, yaitu citra analog dan citra digital.

Citra analog adalah citra yang bersifat kontinu, seperti gambar pada monitor televisi, foto sinar X, foto yang tercetak di kertas foto, lukisan, pemandangan alam, hasil CT scan dan lain sebagainya. Citra analog tidak dapat dipresentasikan dalam komputer sehingga tidak bisa diproses di komputer secara langsung. Oleh sebab itu, agar citra ini dapat diproses di komputer, proses konversi analog ke digital harus dilakukan terlebih dahulu. Citra analog dihasilkan dari alat-alat analog di antaranya adalah video kamera analog, kamera foto analog dan CT scan.

Citra digital adalah citra yang dapat diolah oleh komputer. 


\section{Akuisisi Citra}

Akuisisi citra adalah tahap awal untuk mendapatkan citra digital (Sutoyo, et al., 2009). Tujuan akuisisi citra adalah untuk menentukan data yang diperlukan dan memilih metode perekaman citra digital. Tahap ini dimulai dari objek yang akan diambil gambarnya, persiapan alat-alat, sampai pada pencitraan. Pencitraan adalah proses untuk mentranformasi citra analog menjadi citra digital. Beberapa alat yang dapat digunakan untuk pencitraan di antaranya adalah video kamera, kamera digital, scanner dan sinar infra merah. Hasil dari akuisisi citra ini ditentukan oleh kemampuan sensor untuk mendigitalisasi sinyal yang terkumpul pada sensor tersebut.

\section{Jaringan Syaraf Biologi}

Jaringan syaraf biologi terdiri atas banyak elemen pemroses sederhana yang disebut neuron, sel, unit atau simpul (Putra, 2010). Sebagai bahan perbandingan, otak seekor cacing diperkirakan memiliki 1000 neuron dan otak manusia memiliki sekitar 100 miliar. Setiap sel syaraf berhubungan dengan sel syaraf lainnya memakai saluran komunikasi yang teratur dengan suatu bobot penghubung. Neuron bekerja berdasarkan impuls atau sinyal yang diberikan pada neuron (Siang, 2009). Neuron meneruskannya pada neuron lain. Diperkirakan manusia memiliki $10^{12}$ neuron dan $6,10^{18}$ sinapsis. Dengan jumlah yang begitu banyak, otak mampu mengenali pola, melakukan perhitungan dan mengontrol organ-organ tubuh dengan kecepatan yang lebih tinggi dibandingkan komputer digital. Sebagai perbandingan, pengenalan wajah seseorang yang sedikit berubah (misal memakai topi, memiliki jenggot, dan lain-lain) akan lebih cepat dilakukan manusia dibandingkan komputer.

Pada waktu lahir, otak mempunyai struktur yang menakjubkan karena kemampuannya membentuk sendiri aturanaturan atau pola berdasarkan pengalaman yang diterima. Jumlah dan kemampuan neuron berkembang seiring dengan pertumbuhan fisik manusia, terutama pada umur 0-2 tahun. Pada 2 tahun pertama umur manusia terbentuk 1 juta sinapsis per-detiknya.

Pada dasarnya neuron memiliki 4 daerah utama, yaitu:

\section{Sel Tubuh atau Soma}

Sel tubuh atau soma merupakan jantungnya sel yang memiliki inti (nucleus). Soma bertugas memproses nilai masukan dari semua dendrit yang terhubung dengannya menjadi suatu keluaran. Soma memiliki dua cabang yaitu dendrit dan axon.

\section{Dendrit}

Dendrit merupakan suatu perluasan dari soma yang menyerupai rambut dan bertindak sebagai saluran untuk menerima masukan dari sel syaraf lainnya melaui sinapsis.

\section{Axon}

Neuron biasanya hanya memiliki satu axon yang tumbuh dari bagian soma dan disebut dengan axon hillock. Axon menyalurkan sinyal elektrik yang dihasilkan pada bagian bawah dari axon hillock. Sinyal elektrik digunakan oleh neuron untuk menyampaikan informasi atau sinyal ke otak dengan semua sinyal sama. Oleh karena itu, otak menentukan jenis informasi yang diterima berdasarkan jalur yang membawa sinyal. Otak kemudian menganalisis dan menafsirkan jenis informasi yang diterima. Myelin adalah materi lemak yang melindungi syaraf. Fungsinya seperti lapisan pelindung pada kabel listrik dan memudahkan syaraf untuk mengirim impulsnya dengan cepat. Tidak semua bagian axon terbungkus dengan myelin. Bagian yang tidak terbungkus ini disebut nodus ranvier. Pada nodus ini, sinyal yang mengalir dan mengalami penurunan akan diperkuat lagi. Hal ini akan memastikan bahwa perjalanan sinyal pada axon mengalir cepat dan tetap konsisten.

\section{Sinapsis}

Sinapsis merupakan bagian kontak (tempat) terjadinya pertukaran sinyal antar dua neuron. Neuron sebenarnya secara fisik tidak berhubungan. Mereka dipisahkan oleh synaptic cleft. Neuron yang mengirim sinyal disebut dengan sel presynaptic, sedangkan neuron yang menerima sinyal disebut dengan sel postsynaptic (Putra, 2010).

Neuron biologi merupakan sistem yang "fault tolerant" dalam 2 hal (Siang, 2009). Pertama, manusia dapat mengenali sinyal masukan yang agak berbeda dari yang pernah kita terima sebelumnya. Sebagai contoh, manusia sering dapat mengenali seseorang yang wajahnya pernah dilihat dari foto, atau dapat mengenali seseorang yang wajahnya agak berbeda karena sudah lama tidak ditemuinya.

Kedua, otak manusia tetap mampu bekerja meskipun beberapa neuronnya tidak mampu bekerja dengan baik. Jika sebuah neuron rusak, neuron lain kadang-kadang dapat dilatih untuk menggantikan fungsi sel yang rusak tersebut.

\section{Jaringan Syaraf Tiruan}

Jaringan syaraf tiruan merupakan model jaringan syaraf yang meniru prinsip kerja dari neuron otak manusia (Putra, 2010). JST pertama 
kali muncul setelah model sederhana dari neuron buatan diperkenalkan oleh McCulloch dan Pitts pada tahun 1943. Model sederhana tersebut dibuat berdasarkan fungsi neuron biologis yang merupakan dasar unit pensinyalan dari sistem syaraf.

JST memiliki beberapa kemampuan seperti yang dimiliki otak manusia, yaitu:

a. Kemampuan untuk belajar dari pengalaman.

b. Kemampuan melakukan perumpamaan terhadap masukan baru dari pengalaman yang dimilikinya.

c. Kemampuan memisahkan karakteristik penting dari masukan yang mengandung data yang tidak penting.

JST ditentukan oleh 3 hal (Siang, 2009):

Pola hubungan antar neuron (disebut arsitektur jaringan)

a. Metode untuk menentukan bobot penghubung (disebut metode training/learning/algoritma)

b. Fungsi aktivasi gambar 2

Sebagai contoh, perhatikan neuron $Y$ pada

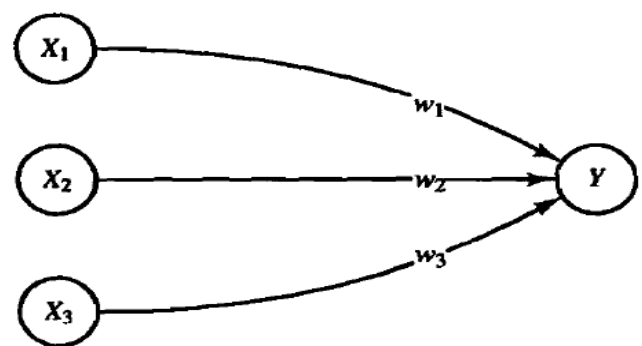

Gambar 2. Jaringan Syaraf Tiruan Sederhana

JST dapat diaplikasikan kedalam pengenalan pola. Secara umum pengenalan pola adalah suatu ilmu untuk mengklasifikasikan atau menggambarkan sesuatu berdasarkan pengukuran kuantitatif fitur (ciri) atau sifat utama dari suatu objek (Putra, 2010). Pola sendiri adalah suatu entitas yang terdefinisi dan dapat diidentifikasikan serta diberi nama. Sidik jari adalah suatu contoh pola. Pola bisa merupakan kumpulan hasil pengukuran atau pemantauan dan bisa dinyatakan dalam notasi matriks atau vektor. Pengenalan pola telah dikembangkan adalah pengenalan secara otomatis karakter tulisan tangan (angka atau huruf), dengan variasi yang sangat banyak di ukuran, posisi dan gaya tulisan (Fausett, 1994). Seperti jaringan Backpropagation yang telah digunakan untuk mengenali tulisan tangan kode pos.

JST dapat dibagi lagi menurut jenis pelatihannya. Dalam JST ada dua macam pelatihan yang dikenal, yaitu pelatihan terbimbing dan tak terbimbing (Siang, 2009).

Dalam pelatihan terbimbing, terdapat sejumlah pasangan data (masukan dan keluaran) yang digunakan untuk melatih jaringan hingga diperoleh bobot yang diinginkan. Pasangan data tersebut berfungsi sebagai "guru" untuk melatih jaringan hingga diperoleh bentuk yang terbaik. "Guru" akan memberikan informasi yang jelas tentang bagaimana sistem harus mengubah dirinya untuk meningkatkan kerjanya.

Pada setiap kali pelatihan, suatu input diberikan ke jaringan. Jaringan akan memproses dan mengeluarkan keluaran. Selisih antara keluaran jaringan dengan target (keluaran yang diinginkan) merupakan error. Jaringan akan memodifikasi bobot sesuai dengan error tersebut.

Sebaliknya, dalam pelatihan tak terbimbing tidak ada guru yang akan mengarahkan proses pelatihannya, perubahan bobot jaringan dilakukan berdasarkan parameter tertentu dan jaringan dimodifikasi menurut ukuran parameter tersebut. Contohnya adalah jaringan lapisan kompetitif.

Selain jenis pelatihan yang tidak kalah penting dalam JST adalah fungsi aktivasi. Kegunaan fungsi aktivasi sudah dijelaskan di atas, yaitu untuk menentukan keluaran. Banyak fungsi aktivasi yang dapat digunakan di antaranya fungsi-fungsi goniometri dan hiperboliknya, fungsi unit step, impuls, dan sigmoid (Purnomo, et al., 2006). Tetapi yang lazim digunakan adalah fungsi sigmoid, karena dianggap lebih mendekati kinerja sinyal pada otak manusia. Pada umumnya fungsi aktivasi membangkitkan sinyal-sinyal unipolar atau bipolar. Fungsi sigmoid, dapat juga dibuat untuk jenis unipolar maupun bipolar.

\section{Jaringan Backpropagation}

Backpropagation merupakan algoritma pembelajaran yang terbimbing(Kusumadewi, 2004). Algoritma Backpropagation menggunakan error keluaran untuk mengubah nilai bobotbobotnya dalam arah mundur. Untuk mendapatkan error ini, tahap perambatan maju harus dilakukan terlebih dahulu.

Arsitektur yang digunakan dalam jaringan Backpropagation merupakan arsitektur lapisan jamak (Siang, 2009). Karena merupakan jaringan lapisan jamak, maka Backpropagation memiliki lapisan tersembunyi.

Dan dalam jaringan Backpropagation, fungsi aktivasi yang digunakan harus memenuhi beberapa syarat, yaitu: kontinu, terdifferensial dengan mudah dan merupakan fungsi yang tidak turun. Salah satu fungsi yang memenuhi ketiga syarat tersebut sehingga sering digunakan adalah fungsi sigmoid biner. Dan fungsi lain yang sering digunakan adalah fungsi sigmoid bipolar yang memiliki range $(-1,1)$. 


\section{Konvergensi}

Definisi. sebuah barisan $X=\left(x_{n}\right)$ di $\mathbb{R}$ dikatakan konvergen untuk setiap $x \in \mathbb{R}$, atau $x$ dikatakan limit $\left(x_{n}\right)$, jika untuk setiap $\varepsilon>0$ ada bilangan asli $K(\varepsilon)$ sedemikian sehingga untuk setiap $n \geq K(\varepsilon), \quad x_{n}$ memenuhi $\left|x_{n}-x\right|<$ $\varepsilon$ (Bartle dan Sherbert, 2000).

Jika sebuah barisan memiliki limit, disebut konvergen. Tapi jika tidak memiliki limit maka disebut divergen.

Berikut ini adalah beberapa konsep dasar tentang definisi yang berkaitan dengan limits yang digunakan sebagai dasar untuk mengevaluasi konvergensi atau sifat asimtotis dari suatu estimator (Suhartono, 2007).

Definisi.Misalkan $b_{n}$ adalah suatu barisan bilangan riil. Jika ada suatu bilangan riil $b$ dan jika untuk setiap bilangan riil $d>0$ ada suatu bilangan bulat $N(d)$ sedemikan hingga untuk semua $n \geq N(d),\left|b_{n}-b\right|<d$ maka $b$ merupakan limit dari barisan $\left\{b_{n}\right\}$.

Definisi. (i) Suatu barisan $\left\{b_{n}\right\}$ dikatakan sebanyak-banyaknya pada orde $n^{\prime}$, dinotasikan $b_{n}=O\left(n^{\prime}\right)$, jika untuk beberapa bilangan riil terbatas $\Delta>0$, ada suatu bilangan bulat terbatas $N$ sedemikan hingga untuk semua $n \geq$ $N,\left|n^{-1} b_{n}\right|<\Delta$. (ii) Suatu barisan $\left\{b_{n}\right\}$ adalah pada orde lebih kecil dari $n^{\prime}$,dinotasikan $b_{n}=o\left(n^{\prime}\right)$, jika untuk setiap bilangan riil $d>0$ ada suatu bilangan bulat terbatas $N(d)$ sedemikian hingga untuk semua $n \geq N(d),\left|n^{-1} b_{n}\right|<d, \quad$ yaitu $n^{-1} b_{n} \rightarrow 0$.

\section{Tes Rasio dan Deret Taylor}

Tes rasio sangat berguna menentukan apakah deret yang diberikan konvergen (Stewart, 2010).

a. Jika $\lim _{n \rightarrow \infty}\left|\frac{a_{n+1}}{a_{n}}\right|=L<1$, maka $\operatorname{deret} \sum_{n=1}^{\infty} a_{n}$ adalah konvergen.

b. Jika $\quad \lim _{n \rightarrow \infty}\left|\frac{a_{n+1}}{a_{n}}\right|=L>1$ atau

$\lim _{n \rightarrow \infty}\left|\frac{a_{n+1}}{a_{n}}\right|=\infty$ maka deret $\sum_{n=1}^{\infty} a_{n}$ adalah divergen.

c. Jika $\lim _{n \rightarrow \infty}\left|\frac{a_{n+1}}{a_{n}}\right|=1$, maka tes rasio tidak dapat ditentukan. Tidak ada hasil yang bisa ditentukan apakah $\sum_{n=1}^{\infty} a_{n}$ konvergen atau divergen.

\section{Deret Taylor}

Teorema Taylor. Andaikan $f$ sebuah fungsi yang memiliki turunan dari semua tingkatan dalam suatu selang $[a-r, a+r]$. Syarat perlu dan cukup agar menjadi deret Taylor adalah

$$
\begin{aligned}
& f(a)+f^{\prime}(a)(x-a) \\
& +\frac{f^{\prime \prime}(a)(x-a)^{2}}{2 !}+\cdots+ \\
& \frac{f(n)(x-a)^{n}}{n !}
\end{aligned}
$$

Apabila $a=0$, maka deret tersebut disebut deret MacLaurin.

\section{Spektroskopi Infra Merah}

Spektroskopi infra merah merupakan salah satu alat yang banyak digunakan untuk mengidentifikasi senyawa baik alami maupun buatan (Habsari, 2010). Bila sinar infra merah dilewatkan melalui cuplikan senyawa organik, maka sejumlah frekuensi akan diserap sedang frekuensi yang lain diteruskan atau ditransmisikan tanpa diserap. Gambaran antara persen absorbansi atau persen transmitansi lawan frekuensi akan menghasilkan suatu spektrum infra merah. Transisi yang terjadi didalam serapan infra merah berkaitan dengan perubahan-perubahan vibrasi dalam molekul. Daerah radiasi spektroskopi infra merah berkisar pada bilangan gelombang $1280-10 \mathrm{~cm}^{-1}$ atau pada panjang gelombang 0,78-1000 $\mu \mathrm{m}$.

Dilihat dari segi aplikasi dan instrumentasi spektroskopi infra merah dibagi ke dalam tiga jenis radiasi yaitu infra merah dekat, infra merah pertengahan, dan infra merah jauh.

Ada 2 jenis instrmentasi untuk absorbsi infra merah yaitu, instrumentasi dispersi (konvensional) yang hanya digunakan untuk analisis kualitatif dan instrumentasi yang menggunakan Fourier Transform (FTIR) dapat digunakan untk analisis kuantitatif dan kualitatif .

Spektroskopi FTIR (fourier transform infrared) merupakan salah satu teknik analitik yang sangat baik dalam proses identifikasi struktur molekul suatu senyawa. Komponen utama spektroskopi FTIR adalah interferometer Michelson yang mempunyai fungsi menguraikan (mendispersi) radiasi infra merah menjadi komponen-komponen frekuensi. Penggunaan interferometer Michelson tersebut memberikan keunggulan metode FTIR dibandingkan metode spektroskopi infra merah konvensional maupun metode spektroskopi yang lain. Di antaranya adalah informasi struktur molekul dapat diperoleh secara tepat dan akurat (memiliki resolusi yang tinggi). Keuntungan yang lain dari metode ini adalah dapat digunakan untuk mengidentifikasi sampel dalam berbagai fase (gas, padat atau cair). Kesulitan-kesulitan yang ditemukan dalam identifikasi dengan spektroskopi FTIR dapat ditunjang dengan data yang diperoleh dengan menggunakan metode spektroskopi yang lain.

Uji kandungan lemak babi dengan metode FTIR telah ditemukan adanya kekhasan vibrasi ulur C-H pada sampel lemak babi yang berbeda dengan lemak hewani lainnya. Hasil yang diperoleh menunjukkan bahwa mesin FTIR sangat berpotensi digunakan sebagai alat untuk mendeteksi lemak babi secara cepat dengan hasil yang konsisten. 


\section{PEMBAHASAN}

Sebelum melakukan pelatihan data, maka yang harus disiapkan adalah data pelatihan, dan data pelatihan diambil dari data gelombang spektra sapi dan babi, Disini $x_{n}$ adalah bilangan gelombang dan $y_{n}$ adalah absorbansi (sinar-x yang diserap oleh benda dan diteruskan untuk mengetahui vibrasi molekulnya). Dan kemudian akan diinterpolasi lagrange untuk mengetahui apropksimasi fungsi dari data berpasangan. Berikut adalah data bilangan gelombang dan absorbansi untuk data babi.

Tabel 1. Bilangan Gelombang dan Absorbansi pada data babi

\begin{tabular}{ccll}
\hline Bilangan gelombang & \multicolumn{2}{l}{ Absorbansi } \\
\hline $\boldsymbol{x}_{\mathbf{0}}=970,192166$ & $y_{0}=$ & $-0,000009$ \\
\hline $\boldsymbol{x}_{\mathbf{1}}=972,120977$ & $y_{1}=$ & 0,000002 \\
\hline $\boldsymbol{x}_{\mathbf{2}}=974,049789$ & $y_{2}=$ & 0,000003 \\
\hline $\boldsymbol{x}_{\mathbf{3}}=975,9786$ & $y_{3}=$ & $-0,000002$ \\
\hline $\boldsymbol{x}_{\mathbf{4}}=977,907411$ & $y_{4}=$ & $-0,000006$ \\
\hline $\boldsymbol{x}_{\mathbf{5}}=979,836223$ & $y_{5}=$ & $-0,000003$ \\
\hline $\boldsymbol{x}_{\mathbf{6}}=981,765034$ & $y_{6}=$ & $-0,000004$ \\
\hline $\boldsymbol{x}_{\mathbf{7}}=983,693846$ & $y_{7}=$ & $-0,000015$ \\
\hline $\boldsymbol{x}_{\mathbf{8}}=985,622657$ & $y_{8}=$ & $-0,000007$ \\
\hline
\end{tabular}

Data bilangan gelombang dan absorbansi pada tabel di atas diinnterpolasi lagrange, sehingga menghasilkan persamaan 2 berikut ini

$$
\begin{aligned}
P(x)=\quad & -1,035741567042484 \cdot 10^{-11} x^{8} \\
& +8,104872585865455 \cdot 10^{-8} x^{7} \\
& -2,774703359707413 \cdot 10^{-4} x^{6} \\
& +0,542808208062731 x^{5} \\
& -6,636724626885896 \cdot 10^{2} x^{4} \\
& +5,193243594766944 \cdot 10^{5} x^{3} \\
& -2,539809476507496 \cdot 10^{8} x^{2} \\
& +7,097788748923267 \cdot 10^{10} x \\
& -8,678018906807824 \cdot 10^{12}
\end{aligned}
$$

Sehingga didapatkan gambar 3 sebagai grafik data pelatihan, dan gambarnya adalah sebagai berikut

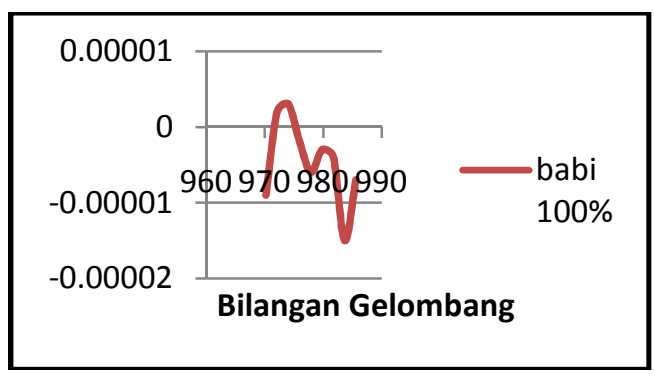

Gambar 3. Gelombang Spektra Babi

Untuk data sapi dengan alat FTIR, didapatkan bilangan gelombang dan data absorbansi pada tabel 2 berikut.
Tabel 2. Bilangan Gelombang dan Absorbansi pada data sapi

\begin{tabular}{lll}
\hline Bilangan gelombang & \multicolumn{2}{l}{ Absorbansi } \\
\hline $\boldsymbol{x}_{\mathbf{0}}=970,192166$ & $y_{0}=0.00005$ \\
\hline $\boldsymbol{x}_{\mathbf{1}}=972,120977$ & $y_{1}=0.000034$ \\
\hline $\boldsymbol{x}_{\mathbf{2}}=974,049789$ & $y_{2}=$ & -0.000006 \\
\hline $\boldsymbol{x}_{\mathbf{3}}=975,9786$ & $y_{3}=$ & -0.000043 \\
\hline $\boldsymbol{x}_{\mathbf{4}}=977,907411$ & $y_{4}=$ & -0.000061 \\
\hline $\boldsymbol{x}_{\mathbf{5}}=979,836223$ & $y_{5}=$ & -0.00006 \\
\hline $\boldsymbol{x}_{\mathbf{6}}=981,765034$ & $y_{6}=$ & -0.000041 \\
\hline $\boldsymbol{x}_{\mathbf{7}}=983,693846$ & $y_{7}=$ & -0.000011 \\
\hline $\boldsymbol{x}_{\mathbf{8}}=985,622657$ & $y_{8}=$ & 0.000013 \\
\hline
\end{tabular}

Setelah itu data bilangan gelombang dan absorbansi diinnterpolasi lagrange, sehingga didapatkan aproksimasi fungsi data berpasangannya adalah,

$$
\begin{aligned}
P(x)= & 7,897573065875410 \cdot 10^{-12} x^{8} \\
& -6,180374054490586 \cdot 10^{-8} x^{7} \\
& +2,115981828265967 \cdot 10^{-4} x^{6} \\
& -0.413970186280669 x^{5} \\
& +5,061791113327844 \cdot 10^{2} x^{4} \\
& -3,961114096958705 \cdot 10^{5} x^{3} \\
& +1,937351871176862 \cdot 10^{8} x^{2} \\
& -5,414515674767383 \cdot 10^{10} x \\
& +6,62043892617714810^{12}
\end{aligned}
$$

Sehingga didapatkan Gambar 4 berikut ini sebagai grafiknya untuk dijadikan data pelatihan.

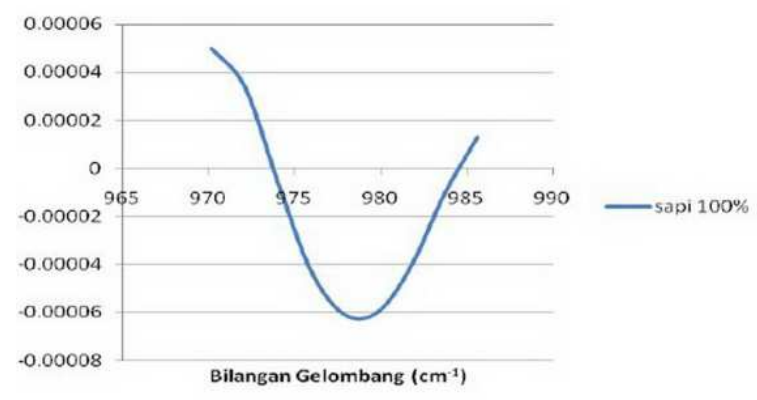

Gambar 4. Gelombang Spektra sapi

Fungsi aktivasi yang akan dibanding adalah fungsi
a. $\tan z$,
b. $\sin z$,
c. $\tanh z$,
d. $\sinh z$,
e. $\arctan z$,
f. $\arcsin z$,
g. $\operatorname{arctanh} z$,
h. $\operatorname{arcsinh} z$

Delapan fungsi aktivasi itu dipilih karena sebagai fungsi non linier yang cukup memadai untuk digunakan sebagai fungsi aktivasi (Kim, 2001). Bentuk kompleks dari fungsi aktivasi yang akan dibandingkan adalah. 


$$
\begin{aligned}
& \tan z=\frac{e^{i z}-e^{-i z}}{i\left(e^{i z}+e^{-i z}\right)} \\
& \sin z=\frac{e^{i z}-e^{-i z}}{2 i} \\
& \tanh z=\frac{e^{z}-e^{-z}}{e^{z}+e^{-z}} \\
& \sinh z=\frac{e^{z}-e^{-z}}{2} \\
& \arctan z=\frac{1}{2 i} \ln \left(\frac{i z+1}{1-i z}\right) \\
& \arcsin z=\frac{1}{i} \ln \left(z i+\sqrt{1-z^{2}}\right) \\
& \operatorname{arctanh} z=\frac{1}{2} \ln \left(\frac{z+1}{1-z}\right) \\
& \operatorname{arcsinh} z=\ln \left(z+\sqrt{z^{2}+1}\right)
\end{aligned}
$$

Kedelapan fungsi aktivasi diata diuji dengan tes rasio untuk mengetahui interval kekonvergenannya. Dan berikut ini hasill dari tes rasio dalam mendeteksi interval kekonvergenannya.

Tabel 3. Perbandingan fungsi aktivasi setelah dicari interval kekonvergenan dengan tes rasio

\begin{tabular}{cl}
$\begin{array}{c}\text { Fungsi } \\
\text { Aktivasi }\end{array}$ & \multicolumn{1}{c}{ Interval Kekonvergenan } \\
\hline $\tan z$ & $-3<z<3$ \\
\hline $\sin z$ & $-1<z<1$ \\
\hline $\tanh z$ & $-3<z<3$ \\
\hline $\sinh z$ & $-1<z<1$ \\
\hline $\arctan z$ & $-1<z<1$ \\
\hline $\arcsin z$ & $-1<z<1$ \\
\hline $\operatorname{arctanh} z$ & $-1<<1$ \\
\hline & $-1<<1$ \\
\hline
\end{tabular}

Untuk interval $-1<<1$ dianggap terlalu terbatas karena metode penentuan bobot yang biasa digunakan adalah metode Nguyen Widrow yang mampu menghasilkan bobot lebih dari satu. Sehingga fungsi aktivasi ini terlalu riskan untuk digunakan sebagai fungsi aktivasi. Untuk tan, memang memiliki interval yang bagus sebagai fungsi aktivasi, tapi setelah dimasukkan nilai ternyata malah menghasilkan nilai kompleks, padahal algoritma yang digunakan dalam pengenalan pola kali ini adalah algoritma bilangan riil. Dan algoritma bilangan riil tidak bisa digunakan untuk bilangan kompleks. Berbeda dengan tanh, fungsi aktivasi ini memiliki interval kekonvergenan yang bagus dan bila dimasukkan nilai menghasilkan nilai bilangan riil. Sehingga fungsi aktivasi tanh sangat bagus untuk digunakan sebagai fungsi aktivasi agar pelatihan bisa mengenali perbedaan karakteristik bentuk gelombang spektra babi dan sapi.

Untuk simulasi program. Berarti akan dibuat program pelatihan Backpropagation untuk mengenali gelombang spektra adalah. clc,clear
$\mathrm{FA}=\mathrm{zeros}(120 * 100,8)$;

$\mathrm{FB}=\mathrm{zeros}\left(120^{*} 100,8\right)$;

for $\mathrm{i}=1: 8$

$A=$ imread(['sapi' num2str(i) '.jpg']);

$[\mathrm{m}, \mathrm{n}, \mathrm{o}]=\operatorname{size}(\mathrm{A})$;

$\mathrm{A} 2=\operatorname{rgb} 2 \operatorname{gray}(\mathrm{A})$;

$\mathrm{A} 3=\mathrm{im} 2 \mathrm{bw}(\mathrm{A} 2$,graythresh(A2));

A4=imresize(A3,[120 100]);

$\mathrm{A} 5=$ reshape $(\mathrm{A} 4,[120 * 1001])$;

$\mathrm{FA}(:, \mathrm{i})=\mathrm{A} 5$;

$\mathrm{B}=$ imread(['babi' num2str(i) '.jpg']);

$[\mathrm{m}, \mathrm{n}, \mathrm{o}]=\operatorname{size}(\mathrm{B})$;

$\mathrm{B} 2=\operatorname{rgb} 2 \operatorname{gray}(\mathrm{B})$;

B3=im2 bw(B2,graythresh(B2));

$\mathrm{B} 4=$ imresize(B3,[120 100]);

$\mathrm{B} 5=\operatorname{reshape}(\mathrm{B} 4,[120 * 1001])$;

$\mathrm{FB}(:, \mathrm{i})=\mathrm{B} 5$;

end

$\mathrm{P}=[\mathrm{FA} \mathrm{FB}]$;

$\mathrm{T}=[\operatorname{ones}(1,8) \operatorname{zeros}(1,8)$;

zeros $(1,8)$ ones $(1,8)]$;

P1 $=[$ P P P P P P P P P P];

$\mathrm{T} 1=[\mathrm{T} \mathrm{T}$ T T T T T T T T];

clear A A2 A3 A4 B B2 B3 B4 B5 i m n o A5

FA FB P T

net=newff(minmax(P1),[50,2],\{'logsig' ,'pur elin'\},'traingd')

net.trainParam.goal $=0.00001$

net.IW $\{1,1\}$;

net.b $\{1\}$;

net.LW $\{2,1\}$;

net.b $\{2\}$;

[y,Pf,Af,e,perf]=sim(net,P1,[],[],T1)

net=train(net,P1,T1)

Gambar 5 dibawah ini menunjukkan saat koding program ini dimasukkan dalam matlab.

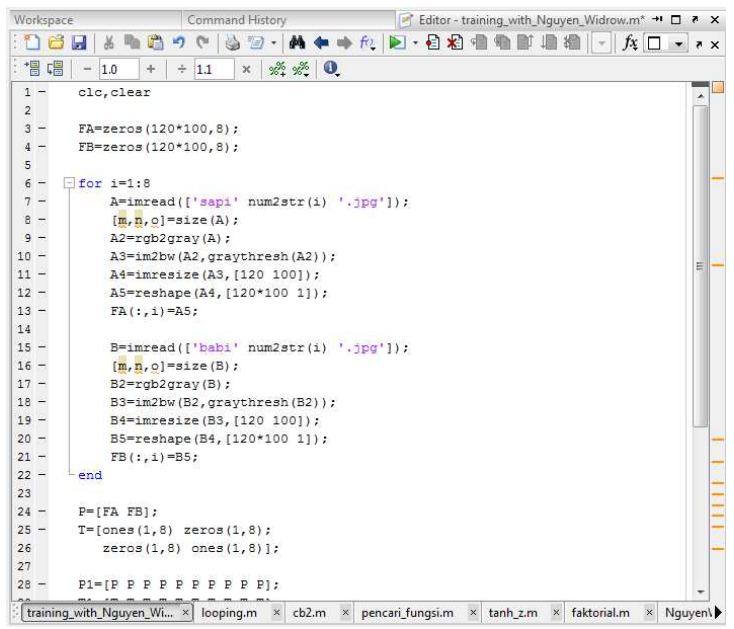

Gambar 5 Koding Program Dimasukkan ke Dalam Matlab

Berikutnya akan dianalisis mengenai tingkat tingginya MSE (mean square error) bila dilihat dari banyaknya jumlah unit tersembunyi dalam satu lapisan tersembunyi dengan laju 
pelatihan $=0,0001$. Berikut tabel jumlah error pelatihan Backpropagation

Tabel 4. MSE Berdasarkan Banyaknya unit dalam satu lapisan tersembunyi

\begin{tabular}{cl} 
Banyak unit & \multicolumn{1}{c}{ MSE } \\
\hline $\mathbf{3}$ & 0,06082 \\
\hline $\mathbf{4}$ & 0,020942 \\
\hline $\mathbf{5}$ & 0,020208 \\
\hline $\mathbf{3 0}$ & 0,0053801 \\
\hline $\mathbf{4 0}$ & 0,0019251
\end{tabular}

Dari kelima uji coba pada tabel di atas dapat disimpulkan bahwa semakin banyak jaringan dalam satu lapisan tersembunyi, maka semakin kecil errornya sehingga semakin bagus hasil pelatihannya. Setelah melakukan pelatihan, maka hasil dari pelatihan disimpan dalam "net".

Kemudian penulis akan menguji coba hasil pelatihan dengan data uji coba, apakah hasil pelatihan mampu mengenali data uji coba dengan benar atau tidak. Pertama-tama disediakan gambar gelombang spektra babi dan sapi. Berikut gambar gelombang spektra babi dan sapi.

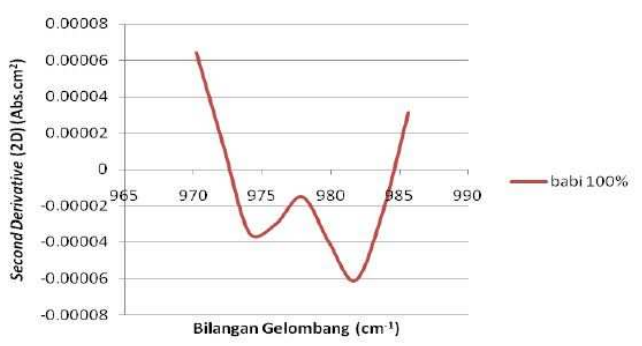

Gambar 6. Gelombang Spektra Babi yang Pertama

Kemudian berikut gambar gelombang spektra sapi.

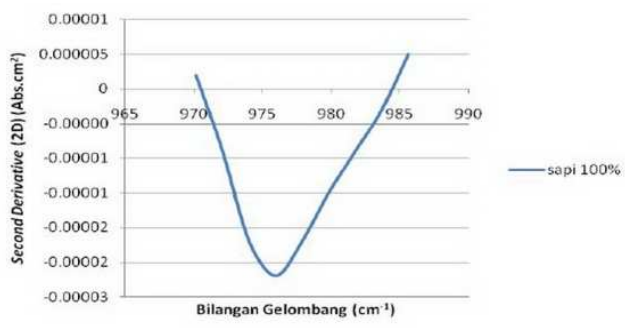

Gambar 7. Gelombang Spektra Sapi yang Pertama

Dua gambar di atas adalah perwakilan dari tiga gambar gelombang spektra babi dan sapi yang digunakan untuk menguji coba hasil pelatihan Backpropagation. Gambar yang dipanggil pertama adalah gambar gelombang spektra babi. Dan setelah program dijalankan, maka hasilnya adalah

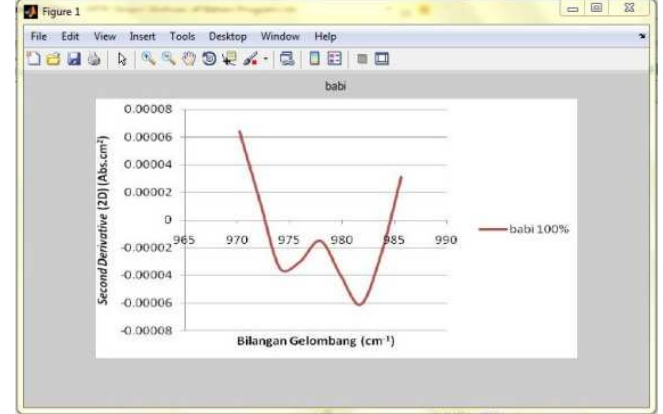

Gambar 8. Program Menebak bahwa

Gambar Gelombang Spektra itu adalah Gelombang Spektra Babi

Cara membaca gambar tebakan di atas dapat dijelaskan dengan gambar di bawah ini.

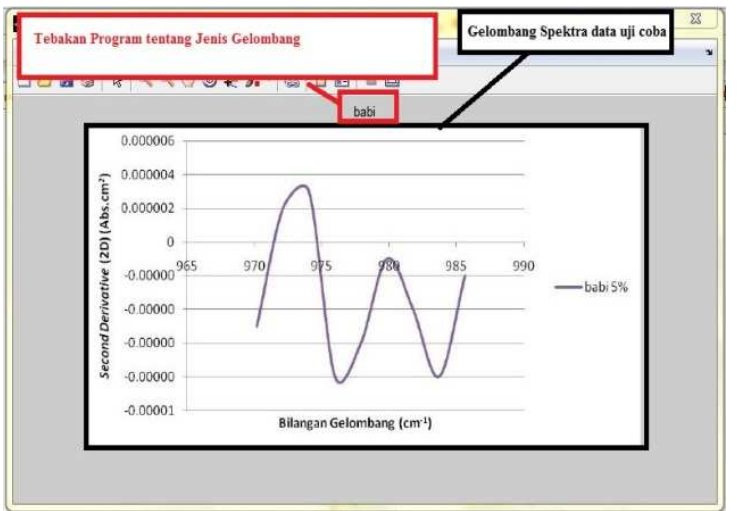

Gambar 9. Tata Cara Membaca Tebakan Program

Dan saat gambar gelombang spektra yang dipanggil adalah gelombang spektra sapi, maka hasilnya adalah

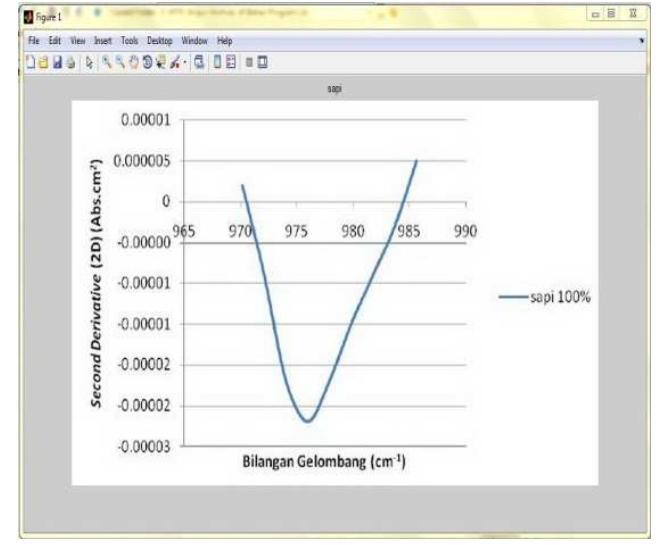

Gambar 10. Program Menebak bahwa Gambar Gelombang Spektra itu adalah Gelombang Spektra Sapi

Dari 6 tebakan program dapat menebak jenis ke-6 gambar gelombang spektra dengan benar. Berarti hasil pelatihan dengan Backpropagation yang menggunakan hasil analisis matematik tadi sudah bagus. 


\section{PENUTUP}

Berdasarkan hasil pembahasan, dapat disimpulkan bahwa fungsi aktivasi tangen hiperbolik adalah fungsi yang terbaik untuk menbedakan gelombang spektra sapi dan babi. Karena menghasilkan bilangan riil dan meiliki interval konvergensi yang cukup memadai untuk beberapa metode seperti Nguyen Widrow ataupun bilangan acak $-0,5$ sampai 0,5 maupun bilangan acak -1 sampai 1 .

Setelah diuji coba pun fungsi aktivasi ini mampu melakukan pelatihan dengan baik, sehingga hasil pelatihan mampu mengenali gambar uji coba dengan sempurna. Fungsi aktivasi dan interval bobot adalah hal yang sangat esensial dalam pelatihan jaringan backpropagation. Karena bila salah menggunakan fungsi aktivasi ataupun bobotnya tidak sesuai sehingga bisa divergen maka pelatihan akan gagal.

Dengan fungsi aktivasi tangen hiperbolik dan interval kekonvergenannya telah mampu membedakan gelombang spektra sapi dan babi. Bila menginginkan pelatihan yang lebih baik, dapat menambah jumlah unit jaringan tersembunyi dalama satu lapisan tersembunyi karena telah diuji coba sampai 40 unit jaringan, bahwa semakin banyak unit jaringan semakin kecil MSE.

Dalam tulisan masih dibahas mengenai fungsi aktivasi dan interval kekonvergenan. Tapi masi belum dibahas mengenai interval bobot yang memiliki konvergensi cepat dan menghasilkan pelatihan yang bagus. Sehingga disarankan untuk meneliti tentang interval bobot yang bagus sehingga menghasilkan pelatihan yang bagus dan konvergensinya yang cepat dengan error yang lebih kecil.

Ucapan terima kasih penulis ucapkan kepada semua pihak yang telah membantu penulis baik berupa bantuan maupun dukungan. Sekian trima kasih.

\section{DAFTAR PUSTAKA}

[1] 'Abdullah bin muhammad bin 'abdurrahman bin ishaq alu syaikh. 2007. Tafsir Ibnu Katsir Jilid 3. Bogor: Pustaka Imam Asy-syafi'i

[2] Ahmad, Y. A. 2008. Al-Qur'an Kitab Kedokteran. Yogyakarta: Sajadah Press

[3] Aizenberg, I. 2011. Complex Valued Neural Networks With Multi-Valued Neurons. Berlin: Springer

[4] Al-Ghazali, I. 2007. Rahasia halal haram. Bandung: Mizania
[5] Anita S. G, P.K. Kalra, \& D.S. Chauhan. (2009). Inversion of Complex BackPropagation Algorithm

[6] Anton, H. 2000. Dasar-dasar Aljabar Linier. Batam: Interaksara

[7] As Sayyid, A. A. M. 2006. Pola Makan Rasulullah. Jakarta: Almahira

[8] Bartle, R. G., \& Sherbert, D. R. 2000. Introduction to Real Analysis. USA: John Willey \& Sons

[9] Fausett, L. 1994. Fundamentals of Neural Networks. New Jersey: Prentice Hall

[10] Habsari, L. Y. D. 2010. Identifikasi Pola Khas Spektra Infra Merah Protein Daging Sapi Dan Babi Rebus Menggunakan Metode Second Derivative (2d). Skripsi Tidak Diterbitkan. Malang: UIN Maliki Malang

[11] Kim, T. \& Adali, T. 2001. Complex Backpropagation Neural Network Using Elementary Transcendental Activation Functions.

[12] Kusumadewi, S. 2004. Membangun Jaringan Syaraf Tiruan (Menggunakan Matlab dan Excel Link). Jakarta: Graha Ilmu

[13] Munir, R. 2008. Metode Numerik. Bandung: Informatika

[14] Purnomo, M. H. \& Kurniawan, A. 2006. Supervised Neural Networks dan Aplikasinya. Yogyakarta: Graha Ilmu

[15] Purwanto, H. dkk. 2005. Aljabar Linier. Jakarta: PT. Ercontara Rajawali

[16] Putra, D. 2010. Pengolahan Citra. Yogyakarta: Andi

[17] Siang, J. J. 2009. Jaringan Syaraf Tiruan dan Pemrogamannya Menggunakan Matlab. Yogyakarta: Andi

[18] Stewart, J. 2010. Calculus Concepts and Contexts. Belmont: Cengage Learning

[19] Suhartono. 2007. Feedforward Neural Networks Untuk Pemodelan Runtun Waktu. Disertasi Tidak Diterbitkan. Yogyakarta: PPs Universitas Gadjah Mada

[20] Sutoyo, T. dkk, 2009. Teori Pengolahan Citra. Yogyakarta: Andi

[21] Wunsh, A. D. 2005, Complex Varibles with Application, USA: pearson Education

[22] Yaqub, A. M. 2009. Kriteria Halal Haram. Jakarta: PT Pustaka Firdaus 